\title{
An examination of the medicinal potential of Scaevola spinescens: Toxicity, antibacterial, and antiviral activities
}

\author{
Ian E. Cock ${ }^{1,2}$, Liisa Kukkonen ${ }^{1}$ \\ ${ }^{1}$ Department of Biomolecular and Physical Sciences, Nathan Campus, Griffith University, 170 Kessels Rd, Nathan, \\ ${ }^{2}$ Environmental Futures Centre, Griffith University, 170 Kessels Rd, Nathan
}

Submitted: 06-01-2011

Revised: 04-04-2011

Published: 08-06-2011

\section{A B S T R A C T}

\begin{abstract}
Background: Scaevola spinescens is an endemic Australian native plant with a history of use as a medicinal agent by indigenous Australians. Yet the medicinal bioactivities of this plant are poorly studied. Materials and Methods: S. spinescens solvent extracts were tested for antimicrobial activity, antiviral activity and toxicity in vitro. Results: All extracts displayed antibacterial activity in the disc diffusion assay. The methanol extract proved to have the broadest specificity, inhibiting the growth of 7 of the 14 bacteria tested (50\%). The water, ethyl acetate, chloroform, and hexane extracts inhibited the growth of $6(42.9 \%), 5(35.7 \%), 5(35.7 \%)$, and $4(28.6 \%)$ of the 14 bacteria tested, respectively. S. spinescens methanolic extracts were equally effective against Gram-positive (50\%) and Gram-negative bacteria (50\%). All other extracts were more effective at inhibiting the growth of Gram-negative bacteria. All extracts also displayed antiviral activity in the MS2 plaque reduction assay with the methanol, water, ethyl acetate, chloroform, and hexane extracts inhibiting $95.2 \pm 1.8 \%, 72.3 \pm 6.3 \%, 82.6 \pm 4.5 \%, 100 \pm 0 \%$ and $47.7 \pm$ $12.9 \%$ of plaque formation, respectively. All S. spinescens extracts were nontoxic in the Artemia fransiscana bioassay with no significant increase in mortality induced by any extract at 24 and $48 \mathrm{~h}$. The only increase in mortality was seen for the water extract at $72 \mathrm{~h}$, although even this extract displayed low toxicity, inducing only $41.7 \pm 23.3 \%$ mortality. Conclusions: The lack of toxicity of the $S$. spinescens extracts and their inhibitory bioactivity against bacteria and viruses validate the Australian Aboriginal usage of $S$. spinescens and indicates its medicinal potential.
\end{abstract}

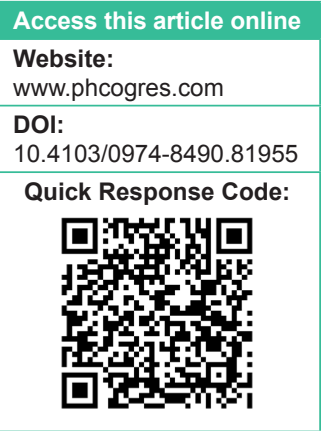

Key words: Antiviral, Australian medicinal plants, maroon bush, medicinal plants, MS2 bacteriophage, Scaevola spinescens

\section{INTRODUCTION}

Scaevola spinescens (commonly known as currant bush, maroon bush, and fanflower; family Goodeniaceae) is a rigid, scrubby bush that grows to approximately $1 \mathrm{~m}$ height and is distributed throughout the drier areas of the Australian continent. It has short hair covered branchlets which in many plants are converted to short sharp spines. In the summer, the shrub develops a profusion of cream to yellow colored flowers which develop to small purple fruits, each containing a single seed. Australian Aborigines used S. spinescens as a medical plant to treat a variety of conditions. ${ }^{[1-3]}$ An infusion of the roots was used to treat

\section{Address for correspondence:}

Dr. Ian Cock, Department Biomolecular and Biomedical

Sciences, Griffith University, Nathan Campus,

170 Kessels Road, Nathan, Queensland 4111, Australia.

E-mail: I.Cock@griffith.edu.au stomach pain and urinary disorders. A decoction of the crushed stem was used to treat boils, rashes, and skin disorders. The whole plant was burnt and the fumes were inhaled to treat colds. Leaves and twigs were steamed and sores treated by exposure to this steam.

Despite its range of traditional medicinal uses, the phytochemistry and therapeutic potential of S. spinescens has not been extensively studied. A study by Semple et al. examined 40 different Australian plants for antiviral bioactivities. ${ }^{\left[{ }^{[4}\right.}$ The study found that $S$. spinescens leaf extracts were capable of inhibiting greater than $25 \%$ of human cytomegalovirus (CMV) late antigen production. More recently, preliminary studies in this laboratory have detected an antiviral bioactivity of the $S$. spinescens methanolic extract against MS2 bacteriophage. ${ }^{[5]}$ These studies demonstrate the antiviral potential of $S$. spinescens and provide support for the traditional Aboriginal use of $S$. spinescens infusions to treat viral diseases. 
S. spinescens also had uses in the treatment of various cancers. This ethnopharmacological knowledge was traditionally passed on by word of mouth instead of written record, and unfortunately, much of our understanding of Aboriginal medicine has been lost as the Aboriginal society has merged into the mainstream Australian society. Accounts exist of aqueous extracts of the $S$. spinescens root bark being used to cure cancer, ${ }^{[2]}$ although their efficacy has yet to be verified in controlled laboratory studies. Anecdotal accounts have also credited $S$. spinescens with an anticancer activity $^{[0]}$ although these also have yet to be verified by rigorous scientific examination.

While individual bioactive compounds are yet to be identified, S. spinescens has been reported to contain high yields of a number of taraxerene type pentacyclic triterpenoids. ${ }^{[7]}$ In particular, high levels of 14-taraxerene3,28-diol (1; myricadiol) were isolated from S. spinescens in this study. Similar pentacyclic triterpenoids isolated from Alchornea latifolia have been linked with the cytotoxic activity toward Hep-G2 and A-431 human cancer cell lines and are potent inhibitors of topoisomerase II. ${ }^{[8]}$ Taraxerene triterpenoids from Laggera pterodonta have also been shown to have an antiviral activity against herpes viruses. ${ }^{[9]}$ Studies have also demonstrated the antibacterial activity of pentacyclic triterpenoids from a variety of plants..$^{[10-12]}$

Surprisingly, the antiseptic and antiviral properties of $S$. spinescens remain largely unstudied. The antibacterial, antifungal, and antiviral properties of other Australian plants are well known. Eucalypts, ${ }^{[13-16]}$ Callistemons, ${ }^{[17]}$ Leptospermums, ${ }^{[8,18-20]}$ Melaleucas, ${ }^{[21,22]}$ and Sysygiums ${ }^{[18,21-24]}$ are all known to have antimicrobial activities. The current study reports on the antibacterial and antiviral properties of S. spinescens extracts as well as their toxicity to determine their potential as antibiotic agents.

\section{MATERIALS AND METHODS}

\section{Plant collection and extraction}

The S. spinescens plant material was provided by Jeannie Cargo of Outback Books Australia (an commercial supplier of $S$. spinescens tea) as a predried and coarse-milled whole plant material. The material was stored at $-30^{\circ} \mathrm{C}$ until use.

One gram of the plant material was weighed into each of five tubes and five different extracts were prepared by adding $50 \mathrm{ml}$ of methanol, water, ethyl acetate, chloroform, and hexane, respectively. All solvents were obtained from Ajax and were of AR grade. The leaf material was extracted in each solvent for $24 \mathrm{~h}$ at $4^{\circ} \mathrm{C}$ with gentle shaking. The extracts were filtered through a filter paper (Whatman no. 54) under vacuum followed by drying by rotary evaporation in Eppendorf concentrator 5301. The resultant dry extract was weighed and redissolved in $10 \mathrm{ml}$ deionized water.

\section{Qualitative phytochemical studies}

Phytochemical analysis of $S$. spinescens extracts was conducted by modified versions of previously described assays. ${ }^{[25-27]}$ The modified assays are briefly outlined below.

\section{Saponins}

One milliliter of the pure extract was added to $1 \mathrm{ml}$ deionized water and shaken vigorously for 30 s. The tubes were allowed to stand for $15 \mathrm{~min}$ and the presence or absence of persistent frothing was noted. Persistent frothing indicated the presence of saponins.

\section{Phenolic compounds}

Phenolic compounds were detected using a modified version of the Folin-Ciocalteu procedure. ${ }^{[27]}$ A total of 200 $\mu \mathrm{l}$ of the crude extract was added to $2 \mathrm{ml}$ of $3 \%$ aqueous sodium carbonate, followed by the addition of $200 \mu \mathrm{l}$ Folin-Ciocalteu reagent. The mixture was allowed to stand for $30 \mathrm{~min}$ at room temperature. The formation of blue/ gray color indicated the presence of phenolic groups.

\section{Water-soluble phenol test}

Two drops of $1 \%$ ferric chloride were added to $500 \mu$ l of each extract. A red color change indicated the presence of water-soluble phenols.

\section{Water insoluble phenol test}

A total of $500 \mu \mathrm{l}$ of dichloromethane, 3 drops of $1 \%$ ferric chloride, and 1 drop of pyridine were added to $500 \mu$ of each extract and mixed. The presence of insoluble phenols was indicated by a color change.

\section{Flavonoids}

Flavonoids were detected using a modified Kumar test. ${ }^{[26]}$ A total of $100 \mu$ l of aqueous sodium hydroxide was added to $1 \mathrm{ml}$ of each extract. The development of an intense yellow color indicated the presence of flavonoids. Also, $100 \mu \mathrm{l}$ of concentrated $\mathrm{HCl}$ was added to the solution. Reversion to the original color confirmed the presence of flavonoids.

\section{Polysteroids}

Polysteroids were detected using a modified version of the Leiberman-Buchard test. ${ }^{[2]}$ Three drops of acetic anhydride were added to $500 \mu \mathrm{l}$ of the crude extract followed by the addition of a few drops of concentrated sulphuric acid. The solution was allowed to stand at room temperature for $5 \mathrm{~min}$. The formation of a blue/green color indicated the presence of polysteroids.

\section{Triterpenoids}

Triterpenoids were detected using a modified version of the 
Salkowski test. ${ }^{[25]}$ One milliliter of the extract was slowly added to $400 \mu \mathrm{l}$ chloroform, followed by careful addition of $400 \mu \mathrm{l}$ concentrated sulphuric acid. The formation of a red/brown/purple color at the interface indicated the presence of triterpenoids.

\section{Cardiac glycosides}

Cardiac glycosides were detected using a modified version of the Keller-Kiliani test. ${ }^{[27]}$ A total of $500 \mu$ l of the extract was added to $500 \mu \mathrm{l}$ glacial acetic acid. A few drops of $1 \%$ aqueous iron chloride and concentrated sulphuric acid were then carefully added. The presence of a red/brown ring on the interface or the formation of a green/blue colour throughout the solution indicated the presence of cardiac glycosides.

\section{Anthraquinones}

Anthraquinones were detected using modified versions of the Kumar and Ajaiyeoba tests. ${ }^{[2,27]}$ The modified Kumar test involved the addition of a few drops of concentrated sulphuric acid to $500 \mu \mathrm{l}$ pure extract, followed by the careful addition of $500 \mu \mathrm{l}$ of ammonia. A rose pink color indicated the presence of free anthraquinones. For the Ajaiyeoba test, $450 \mu \mathrm{l}$ of the crude extract was added to $50 \mu \mathrm{l}$ concentrated $\mathrm{HCl}$ and allowed to stand at room temperature for several minutes. A total of $500 \mu \mathrm{l}$ chloroform was then carefully added. The formation of a rose pink colour indicated the presence of combined anthraquinones.

\section{Tannins}

Tannins were detected using a modified version of the ferric chloride test. ${ }^{[2]}$ Two drops of the $1 \%$ aqueous ferric chloride reagent were added to $500 \mu \mathrm{l}$ of the crude extract. The mixture was observed for the formation of blue, blueblack, green, or green-black coloration which indicated the presence of tannins.

\section{Alkaloids}

Two methods were used to test for the presence of alkaloids.

\section{Mayer's reagent test}

A total of $200 \mu$ l of the pure extract was treated with a few drops of the aqueous solution of hydrochloric acid and 500 $\mu l$ Mayer's reagent. The formation of a white precipitate was taken to indicate the presence of alkaloids.

For Mayer's reagent, mercuric chloride $(1.358 \mathrm{~g})$ was dissolved in $60 \mathrm{ml}$ deionized water. Potassium iodide $(5.0 \mathrm{~g})$ was dissolved in $10 \mathrm{ml}$ deionized water. The mercuric chloride and potassium iodide solutions were mixed and made up to $100 \mathrm{ml}$ with deionized water.

\section{Wagner's reagent test}

A total of $200 \mu$ l of each extract was treated with a few drops of an aqueous solution of hydrochloric acid and 500 $\mu l$ Wagner's reagent. A reddish-brown flocculent precipitate indicated the presence of alkaloids.

For Wagner's reagent, $1.27 \mathrm{~g}$ iodine and $2 \mathrm{~g}$ potassium iodide were dissolved in $5 \mathrm{ml}$ deionized water and made up to a final volume of $100 \mathrm{ml}$ with deionized water.

\section{Antibacterial screening \\ Test microorganisms}

All microbial strains were obtained from Michelle Mendell and Tarita Morais, Griffith University, Australia. Stock cultures of Aeromonas bydropbila, Alcaligenes feacalis, Bacillus cereus, Citrobacterfreundii, Escherichia coli, Klebsiella pneumoniae, Proteus mirabilis, Pseudomonas fluorescens, Salmonella newport, Serratia marcescens, Shigella sonnei, Staphylococcus aureus, Staphylococcus epidermidis, and Streptococcus pyogenes were subcultured and maintained in nutrient broth at $4^{\circ} \mathrm{C}$.

\section{Evaluation of the antimicrobial activity}

The antimicrobial activity of all plant extracts was determined using a modified Kirby-Bauer disc diffusion method. ${ }^{[28]}$ Briefly, $100 \mu$ l of the test bacteria was grown in $10 \mathrm{ml}$ of the fresh nutrient broth until the bacteria reached a count of approximately $10^{8}$ cells $/ \mathrm{ml}$ as determined by direct microscopic determination. One hundred microliters of the microbial suspension was spread onto nutrient agar plates.

The extracts were tested using $5-\mathrm{mm}$ sterilized filter paper discs. Discs were impregnated with $10 \mu \mathrm{l}$ of the test sample, allowed to dry, and placed onto inoculated plates. The plates were allowed to stand at $4^{\circ} \mathrm{C}$ for $2 \mathrm{~h}$ before incubation with the test microbial agents. Plates inoculated with $A$. feacalis, $A$. bydrophila, B. cereus, C. freundii, K. pneumoniae, P. mirabilis, P. fluorescens, and S. marcescens were incubated at $30^{\circ} \mathrm{C}$ for $24 \mathrm{~h}$; then the diameters of the inhibition zones were measured in millimeters. Plates inoculated with E. coli, S. newport, S. sonnei, S. aureus, S. Epidermidis, and $S$. pyogenes were incubated at $37^{\circ} \mathrm{C}$ for $24 \mathrm{~h}$; then the diameters of the inhibition zones were measured. All measurements were to the closest whole millimeter. Each antimicrobial assay was performed in at least triplicate. Mean values are reported in this study. Standard discs of ampicillin $(2 \mu \mathrm{g})$ and chloramphenicol $(10 \mu \mathrm{g})$ were obtained from Oxoid Ltd. and served as positive controls for the antimicrobial activity. Filter discs impregnated with $10 \mu \mathrm{l}$ of distilled water or $10 \mu \mathrm{l}$ of $10 \%$ methanol were used as negative controls.

\section{Minimum inhibitory concentration determination}

The minimum inhibitory concentration (MIC) of the S. spinescens extracts were determined by the disc diffusion 
method across a range of doses. The plant extracts were diluted in deionized water across a concentration range from $5 \mathrm{mg} / \mathrm{ml}$ to $0.1 \mathrm{mg} / \mathrm{ml}$. Discs were impregnated with $10 \mu \mathrm{l}$ of the test dilutions, allowed to dry, and placed onto inoculated plates. The assay was performed as outlined above and graphs of the zone of inhibition versus concentration were plotted for each extract. Linear regression was used to calculate the MIC values.

\section{Screen for antiviral bioactivity}

\section{Viral and bacterial stocks}

MS2 bacteriophage, and F+ Amp + E. coli used in this study were supplied by Dr. Jatinder Sidhu and Dr. Simon Toze of CSIRO, St. Lucia Qld, Australia. S. aureus were obtained from Michelle Mendell, Griffith University. All stock cultures were subcultured and maintained in nutrient broth at $4^{\circ} \mathrm{C}$.

\section{Production of MS2 virus}

A total of $100 \mathrm{ml}$ of nutrient broth $(25 \mathrm{~g} / \mathrm{l})$ containing ampicillin $(100 \mu \mathrm{g} / \mathrm{ml})$ was inoculated with $1 \mathrm{ml} \mathrm{F}+$ Amp + E. coli culture and incubated overnight at $37^{\circ} \mathrm{C}$. The following day, flasks containing $30 \mathrm{ml}$ of nutrient broth (containing $100 \mu \mathrm{g} / \mathrm{ml}$ ampicillin) were inoculated with $1 \mathrm{ml}$ of the $\mathrm{F}+\mathrm{Amp}+$ E. coli overnight culture and incubated for $2 \mathrm{~h}$ at $37^{\circ} \mathrm{C}$ and $160 \mathrm{rpm}$. Once bacterial cells had reached log phase, $1 \mathrm{ml}$ of stock MS2 virus (containing approximately $10^{8}$ plaque forming units) was added and incubated overnight at $35^{\circ} \mathrm{C}$. The solution was centrifuged at $4000 \mathrm{rpm}$ for $10 \mathrm{~min}$ and the supernatant was collected and passed through a $22 \mu \mathrm{m}$ Sarstedt filter. All stock and working solutions were stored at $4^{\circ} \mathrm{C}$ until use.

\section{Soft agar overlay}

A soft agar overlay was prepared to a final concentration of $0.7 \% \mathrm{w} / \mathrm{v}$ agar, $1 \% \mathrm{w} / \mathrm{v}$ glucose, $1 \% \mathrm{w} / \mathrm{v} \mathrm{CaCl}_{2}$ solution, and $1 \% \mathrm{w} / \mathrm{v} \mathrm{MgSO}_{4}$ and autoclaved at $120^{\circ} \mathrm{C}$ for $20 \mathrm{~min}$. The soft agar overlay was allowed to cool to $65^{\circ} \mathrm{C}$; then nalidixic acid was added to a final concentration of $0.4 \%$ $\mathrm{w} / \mathrm{v}$. The overlay was used immediately for the MS2 plaque inhibition assay described below.

\section{MS2 plaque inhibition assay}

The MS2 plaque assay was performed as previously described ${ }^{[5]}$ Briefly, $490 \mu \mathrm{l}$ of the crude plant extract was inoculated with $10 \mu \mathrm{l}$ of MS2 virus (containing approximately $10^{10}$ plaque forming units $/ \mathrm{ml}$ ) and incubated overnight at $4^{\circ} \mathrm{C}$. The solution was added to $500 \mu \mathrm{l}$ S. aureus and incubated at $37^{\circ} \mathrm{C}$ for $20 \mathrm{~min}$. The bacteria/virus/ extract mixture was then added to $3 \mathrm{ml}$ soft agar overlay and immediately poured over premade agar plates $(2.8 \% \mathrm{w} / \mathrm{v}$ agar). Plates were allowed to set for $15 \mathrm{~min}$ at room temp, inverted, and incubated overnight at $37^{\circ} \mathrm{C}$. The following morning plaques were counted and a percentage inhibition recorded. Serial dilution was used to determine the antiviral strength of samples where necessary. Nutrient broth and deionized water were used as negative controls, while the C. sinensis water extract, and UV irradiation (microwave of $10 \mu \mathrm{l}$ virus only for $4 \times 30 \mathrm{~s}$ ) were used as positive controls.

\section{Toxicity screening}

\section{Reference toxins for biological screening}

Potassium dichromate $\left(\mathrm{K}_{2} \mathrm{Cr}_{2} \mathrm{O}_{7}\right.$ AR grade; Chem-Supply, Australia) was prepared as a $1.6 \mathrm{mg} / \mathrm{ml}$ solution in distilled water and was serially diluted in synthetic seawater for use in the Artemia franciscana nauplii bioassay. Mevinphos (2-methoxycarbonyl-1-methylvinyl dimethyl phosphate) was obtained from Sigma-Aldrich as a mixture of cis $(76.6 \%)$ and trans $(23.0 \%)$ isomers and prepared as a $4 \mathrm{mg} /$ $\mathrm{ml}$ stock in distilled water. The stock was serially diluted in artificial seawater for use in the bioassay.

\section{A. franciscana nauplii toxicity screening}

Toxicity was tested using the $A$. franciscana nauplii lethality assay developed by Meyer et al. ${ }^{[29]}$ for the screening of active plant constituents with the following modifications. A. franciscana cysts were obtained from North American Brine Shrimp, LLC, USA (harvested from the Great Salt Lake, UT, USA). Synthetic seawater was prepared using Reef Salt, AZOO Co., USA. Seawater solutions at $34 \mathrm{~g} / 1$ distilled water were prepared prior to use. Two grams of $A$. franciscana cysts was incubated in 11 synthetic seawater under artificial light at $25^{\circ} \mathrm{C}, 2000 \mathrm{Lux}$, with continuous aeration. Hatching commenced within 16-18 h of incubation. Newly hatched A. franciscana (nauplii) were used within $10 \mathrm{~h}$ of hatching. Nauplii were separated from the shells and remaining cysts and were concentrated to a suitable density by placing an artificial light at one end of their incubation vessel, and the nauplii-rich water closest to the light was removed for biological assays. A total of $400 \mu \mathrm{l}$ of seawater containing approximately 42 (mean 41.6, $n=150$, SD 17.8) nauplii was added to wells of a 48-well plate and immediately used for bioassay. The plant extracts were diluted to $4 \mathrm{mg} /$ $\mathrm{ml}$ in seawater for toxicity testing, resulting in a $2 \mathrm{mg} / \mathrm{ml}$ concentration in the bioassay. A total of $400 \mu$ lof the diluted plant extract and the reference toxins were transferred to the wells and incubated at $25 \pm 1^{\circ} \mathrm{C}$ under artificial light (1000 Lux). A negative control (400 $\mu$ l seawater) was run in at least triplicate for each plate. All treatments were performed in at least triplicate. The wells were checked at regular intervals and the number of dead counted. The nauplii were considered moribund if no movement of the appendages was observed within $10 \mathrm{~s}$. After $72 \mathrm{~h}$, all nauplii were sacrificed and counted to determine the total number per well. The $\mathrm{LC}_{50}$ with 95\% confidence limits for each treatment was calculated using probit analysis. ${ }^{[30]}$

\section{Statistical analysis}


Data are expressed as the mean $\pm \mathrm{SD}$ of at least three independent experiments. The paired $t$-test was used to calculate statistical significance between control and treated groups with a $P$-value $<0.05$ considered to statistically significant.

\section{RESULTS}

Liquid extraction yields and qualitative phytochemical screening

The extraction of $1 \mathrm{~g}$ of the dried plant material with various solvents yielded dried plant extracts ranging from $44 \mathrm{mg}$ to $232 \mathrm{mg}$ [Table 1]. Deionized water and chloroform both gave high yields of the dried extracted material (210 and $232 \mathrm{mg}$, respectively) while hexane extracted the lowest mass $(44 \mathrm{mg})$. The dried extracts were resuspended in $10 \mathrm{ml}$ of deionized water resulting in the extract concentrations shown in Table 1.

\begin{tabular}{|c|c|c|}
\hline Solvent & $\begin{array}{l}\text { Mass of the dried } \\
\text { extract } \\
\text { (mg) }\end{array}$ & $\begin{array}{c}\text { Resuspended } \\
\text { extract concentration } \\
(\mathrm{mg} / \mathrm{ml})\end{array}$ \\
\hline Methanol & 116 & 11.6 \\
\hline Deionized water & 210 & 21 \\
\hline Ethyl acetate & 160 & 16 \\
\hline Chloroform & 232 & 23.2 \\
\hline Hexane & 44 & 4.4 \\
\hline
\end{tabular}

Phytochemical studies [Table 2] showed that methanol and water extracted the widest range of phytochemicals. Both showed moderate to high levels of phenolics (water-soluble phenolics only), flavonoids, and tannins with lower levels of saponins present in both extracts. The only difference detected between the methanol and water extracts was the possible presence of low levels of alkaloids in the methanol extract. However, alkaloids were only detected in the methanol extract by the Meyer test. In contrast, the Wagner test was negative for the presence of alkaloids, indicating that if present, the level of alkaloids in the methanol extract was low. No alkaloids were detected in the water extract. The ethyl acetate, chloroform, and hexane extracts all only had detectable levels of water insoluble phenols and only a low response was seen for each solvent.

\section{Antibacterial activity}

A total of $10 \mu \mathrm{l}$ of each extract was tested in the disc diffusion assay against 14 bacteria [Table 3]. All extracts displayed an antibacterial activity, being capable of inhibiting the growth of between 4 and 7 of the bacteria tested. The methanolic extract displayed the broadest antibiotic specificity, inhibiting the growth of 7 of the 14 bacteria tested $(50 \%)$. The methanolic extract was particularly potent against $S$. marcenscens as determined from the zone of inhibition $(10.3 \pm 0.6 \mathrm{~mm})$. The $S$. spinescens water extract also had a broad-range antibacterial specificity inhibiting the growth of 6 of the 14 bacteria tested (42.9\%). The ethyl acetate and chloroform extracts each inhibited 5 of the 14 bacteria tested $(35.7 \%)$ while the hexane extract inhibited 4 of the 14 bacteria tested $(28.6 \%)$.

\begin{tabular}{|c|c|c|c|c|c|}
\hline & Methanol & Deionized water & Ethyl acetate & Chloroform & Hexane \\
\hline \multicolumn{6}{|l|}{ Phenolics } \\
\hline Total phenolics & +++ & +++ & - & - & - \\
\hline Water soluble & ++ & ++ & - & - & - \\
\hline Water insoluble & - & - & + & + & + \\
\hline \multicolumn{6}{|l|}{ Cardiac glycosides } \\
\hline Keller-Kiliani test & - & - & - & - & - \\
\hline \multicolumn{6}{|l|}{ Saponins } \\
\hline Froth persistence & + & + & - & - & \\
\hline \multicolumn{6}{|l|}{ Triterpenes } \\
\hline Salkowski test & - & - & - & - & - \\
\hline \multicolumn{6}{|l|}{ Phytosteroids } \\
\hline Acetic anhydride test & - & - & - & - & - \\
\hline \multicolumn{6}{|l|}{ Alkaloids } \\
\hline Meyer's test & + & - & - & - & - \\
\hline Wagner's test & - & - & - & - & - \\
\hline \multicolumn{6}{|l|}{ Flavonoids } \\
\hline Shinoda test & ++ & ++ & - & - & - \\
\hline Kumar test & ++ & ++ & - & - & - \\
\hline \multicolumn{6}{|l|}{ Tannins } \\
\hline Ferric chloride test & ++ & +++ & - & - & - \\
\hline \multicolumn{6}{|l|}{ Anthraquinones } \\
\hline Free & - & - & - & - & - \\
\hline Combined & - & - & - & - & - \\
\hline
\end{tabular}

+++ indicates a large response; ++ indicates a moderate response; + indicates a minor response; - indicates no response in the assay. 
The methanol extract was the most effective at inhibiting Gram-positive bacterial growth, inhibiting 2 of the 4 bacteria tested (50\%). In contrast, all other extracts inhibited only a single bacteria ( $S$. epidermidis) of the 4 Gram-positive bacteria tested (25\%). The methanol extract was also the most efficient at inhibiting Gramnegative growth, inhibiting the growth of 5 of the 10 bacterial tested $(50 \%)$. In comparison, the growth of 5 Gram-negative bacteria was inhibited by the water extract $(50 \%)$ and 4 Gram-negative bacteria were inhibited by each of the ethyl acetate, chloroform, and hexane extracts $(40 \%)$.

The relative level of the antibacterial activity was further evaluated by determining the MIC values for each extract against the bacterial species which were shown to be susceptible by disc diffusion assays [Table 4]. MICs were evaluated in the current studies by disc diffusion across a range of concentrations. This has previously been determined to be a valid method of MIC determination as MIC values determined by disc diffusion correlate well with those determined by broth dilution assays. ${ }^{[31]}$
The water extract was effective at low concentrations against several bacteria. Indeed, the growth of $A$. faecalis, K. pneumoniae, and P. mirabilis was inhibited at concentrations below $100 \mu \mathrm{g} / \mathrm{ml}$. With the exception of C. freundi (MIC $2501 \mu \mathrm{g} / \mathrm{ml}$ ), the water extract displayed MIC values less than $500 \mu \mathrm{g} / \mathrm{ml}$ for all the bacterial species whose growth it inhibited. Similarly, the ethyl acetate extract also inhibited P. mirabilis at low concentrations (MIC $23.1 \mu \mathrm{g} /$ $\mathrm{ml})$. It was less effective at inhibiting the growth of the four other bacterial species, although in all cases the MIC was less than $500 \mu \mathrm{g} / \mathrm{ml}$. While the methanol extract had the broadest specificity of the extracts [Table 3], it was not as effective against any of these bacteria as the water or ethyl acetate extract, with MIC values ranging from 151.9 to $531.7 \mu \mathrm{g} / \mathrm{ml}$. Also noteworthy was the low MIC value of the chloroform extract against $S$. newport.

\section{Antiviral activity}

Figure 1 shows the formation of MS2 bacteriophage plaques in the presence of the extracts or the positive and negative controls as a percentage of control plaque formation. All extracts displayed an antiviral activity when

Table 3: Antibacterial activity of S. spinescens solvent extracts measured as zones of inhibition

\begin{tabular}{|c|c|c|c|c|c|c|c|c|}
\hline & $\begin{array}{l}\text { Methanol } \\
\text { extract }\end{array}$ & $\begin{array}{l}\text { Water } \\
\text { extract }\end{array}$ & $\begin{array}{c}\text { Ethyl } \\
\text { acetate } \\
\text { extract }\end{array}$ & $\begin{array}{l}\text { Chloroform } \\
\text { extract }\end{array}$ & $\begin{array}{l}\text { Hexane } \\
\text { extract }\end{array}$ & Ampicillin & Chloramphenicol & $\begin{array}{c}\text { Negative } \\
\text { control } \\
\text { (water) }\end{array}$ \\
\hline Gram-negative rods & & & & 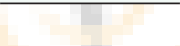 & & & & \\
\hline A. faecalis & - & $6.3 \pm 0.6$ & - & - & - & $15.2 \pm 1.2$ & $6.3 \pm 0.6$ & - \\
\hline A. hydrophilia & - & - & - & - & - & $12.0 \pm 1.0$ & $28.7 \pm 1.6$ & - \\
\hline C. freundi & $6.0 \pm 0$ & $6.7 \pm 1.5$ & - & $7.7 \pm 0.6$ & $7.7 \pm 0.6$ & $8.3 \pm 0.6$ & $15.7 \pm 1.2$ & - \\
\hline E. coli & - & - & - & - & - & $14.7 \pm 0.6$ & $17.3 \pm 0.6$ & - \\
\hline K. pneumoniae & $7.7 \pm 1.2$ & $7.7 \pm 0.6$ & $8.0 \pm 0$ & $7.7 \pm 1.2$ & $9.0 \pm 0$ & $10.3 \pm 0.6$ & $21.3 \pm 1.5$ & - \\
\hline P. mirabilis & $6.0 \pm 1.0$ & $9.3 \pm 0.6$ & $9.7 \pm 1.2$ & - & $9.0 \pm 1.0$ & $17.3 \pm 0.6$ & $8.7 \pm 0.6$ & - \\
\hline P. fluroscens & - & - & - & - & - & $18.2 \pm 0.5$ & $21.2 \pm 1.2$ & - \\
\hline S. newport & $8.0 \pm 1.0$ & - & $7.7 \pm 0.6$ & $8.7 \pm 0.6$ & - & $18.7 \pm 0.6$ & $20.3 \pm 0.6$ & - \\
\hline S. marcenscens & $10.3 \pm 0.6$ & $6.7 \pm 1.2$ & $6.0 \pm 0$ & $6.0 \pm 0$ & $6.3 \pm 0.6$ & - & $14.7 \pm 0.6$ & - \\
\hline S. sonnei & - & - & - & - & - & $14.0 \pm 0$ & $14.3 \pm 0.6$ & - \\
\hline Gram-positive rods & & & & & & & & \\
\hline B. cereus & $7.0 \pm 0$ & - & - & - & - & $26.7 \pm 0.6$ & $13.3 \pm 1.2$ & - \\
\hline Gram-positive cocci & & & & & & & & \\
\hline S. aureus & - & - & - & - & - & $11.7 \pm 2.1$ & $16.0 \pm 1.0$ & - \\
\hline S. epidermidis & $6.3 \pm 0.6$ & $6.3 \pm 0.6$ & $6.3 \pm 0.6$ & $5.7 \pm 0.6$ & - & $26.3 \pm 1.5$ & $12.3 \pm 0.6$ & - \\
\hline S. pyogenes & - & - & - & - & - & $17.0 \pm 1.0$ & $24.0 \pm 1.0$ & - \\
\hline
\end{tabular}

Numbers indicate the mean diameters $(\mathrm{mm})$ of the inhibition of at least triplicate experiments \pm standard deviation. Ampicillin $(2 \mu \mathrm{g})$ and chloramphenicol ( $10 \mu \mathrm{g})$ were used as the positive controls. Artificial seawater was included as a negative control; - = Indicates no growth inhibition.

Table 4: Minimum inhibitory concentrations $(\mu \mathrm{g} / \mathrm{ml})$ of $S$. spinescens extracts against susceptible bacteria

\begin{tabular}{lcccccccc}
\hline & \multicolumn{8}{c}{ MIC $(\boldsymbol{\mu g} / \mathbf{m l})$} \\
\cline { 2 - 9 } & A. faecalis & C. freundi & K. pneumoniae & P. mirabilis & S. newport & S. marcenscens & B. cereus S. epidermidis \\
\hline Methanol extract & - & 353.6 & 581.5 & 151.9 & 197.9 & 374.6 & 353.5 & 531.7 \\
Water extract & 85.3 & 2501.1 & 66.8 & 25.4 & - & 350.3 & - & 489.3 \\
Ethyl acetate extract & - & - & 336.1 & 23.1 & 335.2 & 441.1 & - & 292.7 \\
Chloroform extract & - & 789.2 & 171.2 & - & 75.8 & 495 & - & 409.9 \\
Hexane extract & - & 540.2 & 342 & 239.1 & - & 239.1 & - \\
\hline
\end{tabular}

Numbers indicate the mean MIC values of at least triplicate determinations; $-=$ Indicates no growth inhibition. 
tested in the MS2 plaque bioassay. The methanol and chloroform extracts were particularly effective at inhibiting MS2 plaque formation, inhibiting $95.2 \pm 1.8 \%$ and 100 $\pm 0 \%$ of the plaque formation, respectively. Water and ethyl acetate extracts were also effective, in both cases inhibiting more than $50 \%$ of plaque formation $(72.3 \pm$ $6.3 \%$ and $82.6 \pm 4.5 \%$, respectively). While still capable of inhibiting the formation of MS2 plaque formation, the hexane extract was a less effective antiviral agent than the other extracts tested as determined by $\%$ plaque inhibition $(47.7 \pm 12.9 \%)$.

The S. spinescens extracts were further tested over a range of concentrations to determine the minimum concentration capable of inhibiting $100 \%$ of plaque formation $\left(\mathrm{PI}_{100}\right)$ and the minimum concentration capable of inhibiting $50 \%$ of plaque formation $\left(\mathrm{PI}_{50}\right.$; Table 5). The minimum dosage of the positive control (C. sinensis leaf extract) capable of totally blocking $100 \%$ MS2 plaque formation $\left(\mathrm{PI}_{100}\right)$ was $2540.0 \pm 812.5 \mu \mathrm{g} / \mathrm{ml}$ while the minimum concentration of the C. sinensis leaf extract capable of blocking $50 \%$ of MS2 plaque formation $\left(\mathrm{PI}_{50}\right.$ ) was $612.5 \pm 198.7 \mu \mathrm{g} /$ $\mathrm{ml}$. All of the $S$. spinescens extracts were more effective antiviral agents than the $C$. sinensis control as determined by their lower $\mathrm{PI}_{50}$ values. The chloroform extract proved the most effective, with a $\mathrm{PI}_{50}$ value of $366.9 \pm 167.2 \mu \mathrm{g} /$ $\mathrm{ml}$. The order of effectiveness of MS2 plaque reduction was as follows: chloroform extract $>$ methanol extract $>$ ethyl acetate extract $>$ water extract $>$ hexane extract $>$ C. sinensis control. $\mathrm{PI}_{100}$ values were only obtained for the

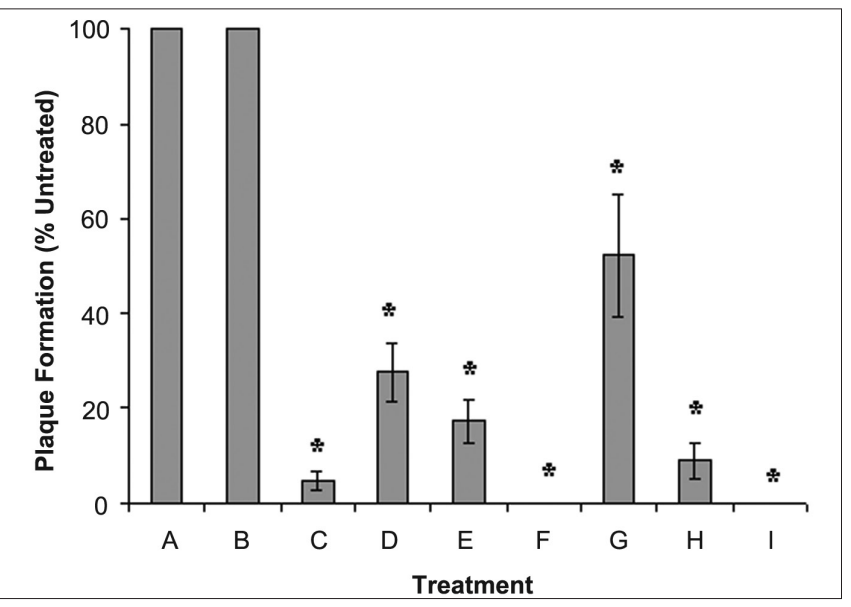

Figure 1: MS2 plaque formation in a $S$. aureus lawn expressed as the percentage of control plaque formation following the incubation of the MS2 with (A) nutrient broth (negative control), (B) deionized water (negative control), (C) methanol extract $(1500 \mu \mathrm{g} / \mathrm{ml}),(D)$ water extract $(2600 \mu \mathrm{g} / \mathrm{ml})$, (E) ethyl acetate extract $(2000 \mu \mathrm{g} / \mathrm{ml})$, (F) chloroform extract $(2900 \mathrm{mg} / \mathrm{ml}),(\mathrm{G})$ hexane extract $(600 \mu \mathrm{g} / \mathrm{ml}),(\mathrm{H})$ C. sinensis leaf water extract $(1000 \mu \mathrm{g} / \mathrm{ml})$, and (I) nutrient agar and microwave irradiation (positive control). All Results are reported as the mean of triplicate assays \pm standard deviation. *indicates statistically significant results
S. spinescens chloroform extract and for the C. sinensis extract control at the concentrations tested in the bioassay. Again, the chloroform extract was the most effective inhibitor of MS2 plaque formation, blocking $100 \%$ of plaque formation at approximately half the concentration of the $C$. sinensis extract control $(1321.2 \pm 602.4 \mu \mathrm{g} / \mathrm{ml}$ compared with $2450.0 \pm 812.5 \mu \mathrm{g} / \mathrm{ml})$.

\section{Quantification of toxicity}

S. spinescens extracts were diluted to a concentration of 4000 $\mu \mathrm{g} / \mathrm{ml}$ in artificial seawater for toxicity testing, resulting in $2000 \mu \mathrm{g} / \mathrm{ml}$ concentrations in the Artemia nauplii lethality bioassay. For comparison, the reference toxins potassium dichromate $(1000 \mu \mathrm{g} / \mathrm{ml})$ and Mevinphos $(2000 \mu \mathrm{g} / \mathrm{ml})$ were also tested in the bioassay. Figure 2 shows the percent mortality induced by each extract and by the controls at various times. The potassium dichromate [Figure $2 \mathrm{~g}$ ] and Mevinphos [Figure 2h] reference toxins were rapid in their onset of mortality. Both reference toxins induced mortality within the first $3 \mathrm{~h}$ of exposure and $100 \%$ mortality was evident following $4-5 \mathrm{~h}$. In contrast, all of the $S$. spinescens extracts displayed mortality rates similar to those of the artificial seawater negative control [Figure 2f] at 24 and $48 \mathrm{~h}$. The water extract did show some increase in mortality by $72 \mathrm{~h}$ although the mortality was still below $50 \%$ so is considered to be of low toxicity. It was not possible to accurately determine an $\mathrm{LC}_{50}$ for any extract as the mortality never exceeded $50 \%$ for any extract at any time tested.

\section{DISCUSSION}

The current study reports on the antimicrobial and antiviral activities of various $S$. spinescens extracts and on their toxicity. The ability of $S$. spinescens extracts to inhibit the growth of both Gram-positive and Gram-negative bacteria is in agreement with previous reports of the antibacterial activity of other Australian native plants that have a history of medicinal usage by Australian Aborigines. The antiseptic properties of the Eucalypts, ${ }^{[13-16]}$ Leptospermums, ${ }^{[8,18-20]}$ and Melaleucas $^{[21,22]}$ have been extensively studied and shown to

$\begin{aligned} & \text { Table 5: Minimum concentrations capable of } \\
& \text { inhibiting } \mathbf{1 0 0 \%}\left(\mathrm{PI}_{100}\right) \text { and } \mathbf{5 0 \%}\left(\mathrm{PI}_{50}\right) \text { of } \mathbf{M S 2}\end{aligned}$
\begin{tabular}{lcc} 
plaque formation of anti-viral plant extracts \\
\hline Phage treatment & $\mathbf{P I}_{100}$ & $\mathbf{P I}_{50}$ \\
\hline S. spinescens methanol extract & $\mathrm{NPI}$ & $405.6 \pm 189.9$ \\
S. spinescens water extract & $\mathrm{NPI}$ & $519.0 \pm 198.7$ \\
S. spinescens ethyl acetate extract & $\mathrm{NPI}$ & $435.1 \pm 224.6$ \\
S. spinescens chloroform extract & $1321.2 \pm 602.4$ & $366.9 \pm 167.2$ \\
S. spinescens hexane extract & $\mathrm{NPI}$ & $557.8 \pm 162.2$ \\
C. sinesis water extract & $2450.0 \pm 812.5$ & $612.5 \pm 198.7$ \\
\hline
\end{tabular}

All $\mathrm{PI}_{100}$ and $\mathrm{PI}_{50}$ values are expressed as $\mu \mathrm{g} / \mathrm{ml} \pm$ standard deviation. NPI denotes that $\mathrm{PI}_{100}$ was not achieved. All values are the mean of at least triplicate determinations. 


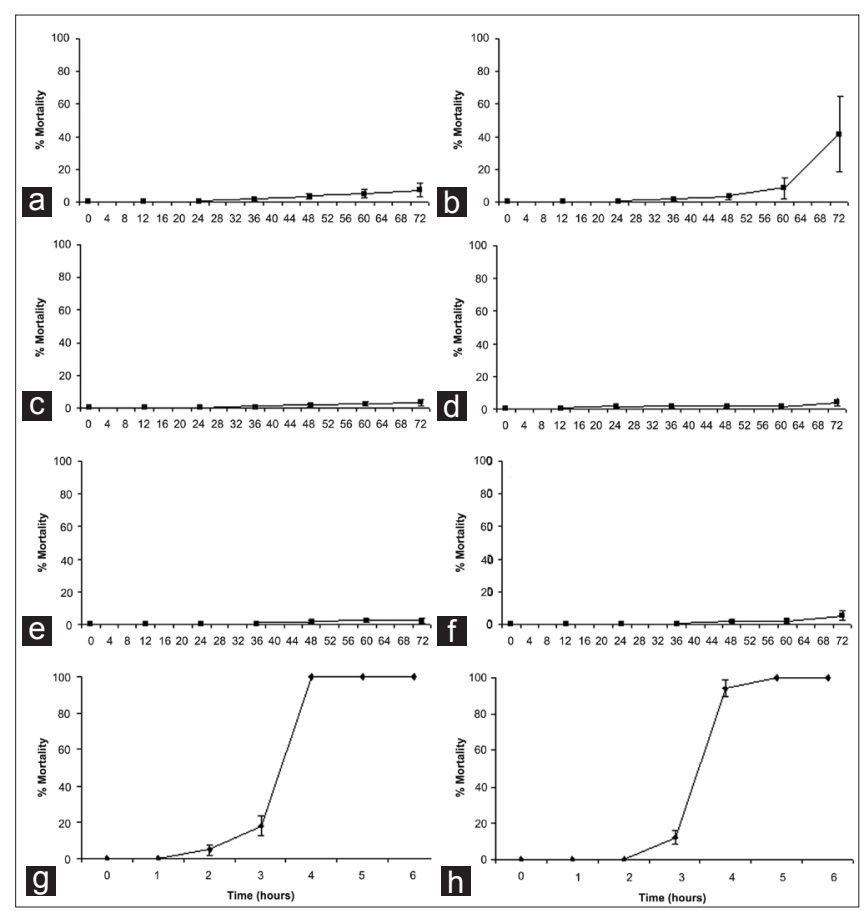

Figure 2: Brine shrimp lethality of the (a) $S$. spinescens methanol extract $(2000 \mu \mathrm{g} / \mathrm{ml})$, (b) S. spinescens water extract $(2000 \mu \mathrm{g} / \mathrm{ml}),($ c) S. spinescens ethyl acetate extract $(2000 \mu \mathrm{g} / \mathrm{ml})$, (d) S. spinescens chloroform extract $(2000 \mu \mathrm{g} / \mathrm{ml})$, (e) S. spinescens hexane extract $(2000$ $\mu \mathrm{g} / \mathrm{ml})$, (f) artificial seawater negative control, (g) potassium dichromate $(1000 \mu \mathrm{g} / \mathrm{ml})$, and $(\mathrm{h})$ Mevinphos $(2000 \mu \mathrm{g} / \mathrm{ml})$. All bioassays were performed in at least triplicate and are expressed as mean \pm standard deviation

inhibit the growth of a wide variety of both Gram-positive and Gram-negative bacteria.

The current study shows Gram-positive and Gramnegative bacteria to be equally susceptible to the $S$. spinescens methanolic extract. All other $S$. spinescens extracts showed a greater specificity for Gram-negative bacteria, although this may be due to the small sample of Gram-positive bacteria tested. The greater susceptibility of Gram-negative bacteria observed in this study is in contrast to previous studies which have reported a greater susceptibility of Gram-positive bacteria toward solvent extracts of South American, ${ }^{[32]}$ African, ${ }^{[33,34]}$ and Australian ${ }^{[35]}$ plant extracts. Results within this laboratory have also confirmed the greater susceptibility of Gram-positive bacteria toward other Australian plant extracts. ${ }^{[18]}$

Individual S. spinescens extract components responsible for the antibacterial potential of the solvent extracts were not identified in the current study. Previous reports have identified various bioactive components of other Australian medicinal plants (Eucalypts, ${ }^{[36]}$ Leptospermum, ${ }^{[37]}$ Melaleucas $\left.{ }^{[38]}\right)$. These plants all contain terpenes including 1,8-cineole, terpinen-4-ol, $\alpha$-pinene, and $\beta$-pinene. Both 1,8-cineole and terpinen-4-ol have an antimicrobial activity. ${ }^{[39,40]}$ Recent studies have also reported on the antibacterial activities of the Callistemons ${ }^{[17]}$ and Syzygiums. ${ }^{[21,22,24,41]}$ It has been postulated that terpene components may also be responsible for the antiseptic properties of these plants. ${ }^{[42]} S$. spinescens has been reported to contain high yields of a number of taraxerene-type pentacyclic triterpenoids, particularly 14-taraxerene3,28-diol (1; myricadiol). ${ }^{[7]}$ While the phytochemistry of the $S$. spinescens extracts was not extensively examined in the current study, phenolic compounds, saponins, flavonoids, and tannins were detected by qualitative assays. Interestingly, no triterpenes were detected in any extract. The presence of other terpenoids was not tested for in the current studies so it is possible that other non-triterpene terpenoids may still be responsible for the antibacterial activity of the $S$. spinescens extracts.

Similarly, the antiviral components were not identified in the current study. All solvent extracts tested displayed an antiviral activity toward MS2 bacteriophage. This is in agreement with a previous study which reported an antiviral activity of $S$. spinescens extracts toward cyclomeglovirus (CMV) ${ }^{[35]}$ Neither study examined the mechanism of the antiviral activity. The extract may be acting by direct viral inactivation, or by disrupting one or more stages of viral replication (cellular attachment and penetration, viral uncoating, and reverse transcription of viral RNA (in the case of RNA viruses, viral nucleic acid synthesis, viral assembly and release). Further studies are required to determine the antiviral mechanism of the $S$. spinescens extracts. Furthermore, while the current studies have detected an antiviral activity toward MS2 bacteriophage and a previous study has shown an anti-CMV activity, ${ }^{[35]}$ the antiviral specificity is yet to be determined toward other viruses. Future studies need to rigorously test $S$. spinescens extracts against a wider panel of viruses to determine their medicinal potential.

Noteworthy was the high antiviral activity in the chloroform extract in the current studies. Of the compounds assayed for, only water insoluble phenols were detected in the chloroform extract, and then only in low levels. It is possible that other classes of compounds not tested for may be responsible for the observed antiviral activity. Fatty acids and other lipids would be expected to be extracted into the chloroform extract. Previous reports have shown various fatty acids and fatty acid derivatives to display an antiviral activity. Lauric acid and monolaurin are effective at inactivating HIV, measles, herpes simplex virus, vesicular somatitis, visna virus, and $\mathrm{CMV}^{[43]}$ Similarly, $9 \mathrm{~S}$, $12 S, 13 S$-trihydroxy-10E-octadecenoic acid has a potent antiviral activity against $\mathrm{H} 1 \mathrm{~N} 1$ and $\mathrm{H} 3 \mathrm{~N} 2$ subtypes of influenza $\mathrm{A}$ and $\mathrm{B}$ viruses. ${ }^{[44]} \mathrm{It}$ is possible that fatty acids extracted into the chloroform extract may be responsible 
for its potent antiviral activity toward MS2. Similarly, fatty acids would also be expected to be extracted with ethyl acetate, hexane, and methanol solvents and therefore may also be responsible for the antiviral activity of these extracts.

The findings reported here also demonstrate that none of the $S$. spinescens extracts displayed significant toxicity toward A. franciscana. Indeed, of the extracts tested, only the water extract was found to induce mortality above that of the negative control, and then only following $72 \mathrm{~h}$ of exposure. As most toxicity studies using Artemia nauplii usually report 24-h and/or 48-h LC 50 s, the reporting of mortality at $72 \mathrm{~h}$ may be excessive. Furthermore, even at the 72 -h time, the mortality induced by the water extract was not high and we were unable to determine an $\mathrm{LC}_{50}$. The extracts were all tested in the current studies at concentrations of 2000 $\mu \mathrm{g} / \mathrm{ml}$ in the bioassay. Previously, compounds with an $\mathrm{LC}_{50}$ of greater than $1000 \mu \mathrm{g} / \mathrm{ml}$ toward Artemia nauplii have been defined as being nontoxic. ${ }^{[29]}$ We report the mortality induction of the extracts at $2000 \mu \mathrm{g} / \mathrm{ml}$ in this study as no increase in mortality was seen for any extract at 1000 $\mu \mathrm{g} / \mathrm{ml}$ at any time (unreported results). It was therefore determined that all $S$. spinescens extracts were nontoxic toward Artemia nauplii.

In conclusion, the results of this study partially validate the traditional Australian Aboriginal usage of S. spinescens to treat bacterial and viral diseases and indicate that S. spinescens is worthy of a further study. Further evaluation of the antibacterial and antiviral properties of these extracts against a more extensive panel of microbial agents is warranted. Likewise, the purification and identification of the bioactive components is needed to examine the mechanisms of action of these agents. While the extracts examined in this report are promising as antibacterial and antiviral agents, caution is needed before these compounds can be applied to medicinal purposes. In particular, further toxicity studies using human cell lines are needed to verify the suitability of these extracts for these purposes.

\section{ACKNOWLEDGMENTS}

The MS2 bacteriophage and the $\mathrm{F}+$ and $\mathrm{F}-\mathrm{Amp}+$ E. coli used in these studies were supplied by Dr. Jatinder Sidhu and Dr. Simon Toze of CSIRO, St. Lucia Qld, Australia. Financial support for this work was provided by School of Biomolecular and Physical Sciences, Griffith University.

\section{REFERENCES}

1. Lassak EV, McCarthy T. Australian medicinal plants. Australia: New Holland Publishers; 2006.
2. Ghisalberti EL. The Goodeniaceae. Fitoterapia 2004;75:429-46.

3. Leyland E. Wajarri wisdom: Food and medicinal plants of the Mullewa/Murchison district of Western Australia as used by the Wajarri people. Yamaji Language Centre, Geraldton, W.A. 2002.

4. Semple SJ, Reynolds GD, O'Leary MC, Flower RL. Screening of Australian medicinal plants for antiviral activity. J Ethnopharmacol 1998;60:163-72.

5. Cock IE, Kalt FR. A modified MS2 Bacteriophage plaque reduction assay for the rapid screening of antiviral plant extracts. Pharmacogn Res 2010;2:221-8.

6. Bushfoods. Available from: http://naturalcancertreatment.org/ content/view/17/35/. [last accessed on 2010 Mar 30].

7. Kerr PG, Longmore RB, Betts TJ. Myricadiol and other taraxerenes from Scaevola spinescens. Planta Medica 1996;62:519-22.

8. Setzer WN, Shen X, Bates RB, Burns JR, McClure KJ, Zhang $\mathrm{P}$, et al. A Phytochemical investigation of Alchornea latifolia. Fitoterapia 2000;71:195-8.

9. Kuljanabhagavad T, Suttisri R, Pengsuparp T, Ruangrungsi N. Chemical structure and antiviral activity of aerial part from Laggera pterodonta. J Health Res 2009;23:175-7.

10. Ahmad M, Ahmad W, Khan S, Zeeshan M, Obaidullah, Nisar M. New antibacterial pentacyclic triterpenes from Myricaria elegans Royle. (tamariscineae). J Enzyme Inhib Med Chem 2008;23:1023-7.

11. Shai LJ, McGaw LJ, Aderogba MA, Mdee LK, Eloff JN. Four pentacyclic triterpenoids with antifungal and antibacterial activity from Curtisia dentata (Burm. F) C.A. Sm. leaves. J Ethnopharmacol 2008;119:238-44.

12. Djoukeng JD, Abou-Mansour E, Tabacchi R, Tapondjou AL, Bouda H, Lontsi D. Antibacterial triterpenes from Syzygium guineense (Myrtaceae). J Ethnopharmacol 2005;101:283-6.

13. Cock IE. Antimicrobial activity of Eucalyptus major and Eucalyptus baileyana methanolic extracts. Int $\mathrm{J}$ Microbiol 2008;6:1.

14. Sartorelli $P$, Marquioreto $A D$, Amaral-Baroli A, Lima ME, Moreno PR. Chemical composition and antimicrobial activity of the essential oils from two species of Eucalyptus. Phytother Res 2007;21:231-3.

15. Delaquis PJ, Stanich K, Girard B, Mazza G. Antimicrobial activity of individual and mixed fractions of dill, cilantro, coriander and eucalyptus essential oils. Int J Food Microbiol 2002;74:101-9.

16. Oyedeji AO, Ekundayo O, Olawore ON, Adeniyi BA, Koenig WA. Antimicrobial activity of the essential oils of five Eucalyptus species growing in Nigeria. Fitoterapia 1999;70:526-8.

17. Sanjai S, Charu G. Antimicrobial potential of Callestemon rigidus. Pharm Biol 2006;44:194-201.

18. Cock IE. Antibacterial activity of selected Australian native plant extracts. Int J Microbiol 2008;4:2.

19. Davis C, Ward W. Control of Chalkbrood disease with natural products. Rural Industries Research and Development Corporation, Canberra, Australia. 2003.

20. Weston RJ, Brocklebank LK, Lu Y. Identification of quantitative levels of antibacterial components of some New Zealand honeys. Food Chem 2000;70:427-35.

21. Carson CF, Hammer KA, Riley TV. Melaleuca alternifolia (Tea Tree) Oil: A Review of Antimicrobial and Other Medicinal Properties. Clin Microbiol Rev 2006;19:50-62.

22. Papadopoulos CJ, Carson CF, Hammer KA, Riley TV. Susceptibility of pseudomonads to Melaleuca alternifolia (tea tree) oil and components. J Antimicrob Chemother 2006;58: 449-51.

23. Arora DS, Kaur GJ. Antibacterial activity of some Indian medicinal plants. J Nat Med 2007;61:313-7. 
24. Park MJ, Gwak KS, Yang I, Choi WS, Jo HJ, Chang JW, et al. Antifungal activities of the essential oils of Syzygium aromaticum (L.) Mer. Et Perry and Leptospermum petersonii Bailey and their constituents against various dermatophytes. J Microbiol 2007;45:460-5.

25. Djipa CD, Delmée M, Quetin-Leclercq J. Antimicrobial activity of bark extracts of Syzygium jambos(L.) Alston (Myrtaceae). J Ethnopharmacol 2000;71:307-13.

26. Duraipandiyan V, Ayyanar M, Ignacimuthu S. Antimicrobial activity of some ethnomedicinal plants used by Paliyar tribe from Tamil Nadu, India. BMC Complement Altern Med 2006;6:35.

27. Oyedapo OO, Sab FC, Olagunju JA. Bioactivity of fresh leaves of Lantana camara. Biomed Lett 1999;59:175-83.

28. Agarwal SK, Singh AS, Lakshmi V, Verma S, Kumar S. Chemistry and Pharmacology of Rhubarb (Rheum species) - A Review. J Sci Ind Res 2001;60:1-9.

29. Harborne JB, Williams CA. Anthocyanins and other flavonoids. Nat Prod Rep 2001;18:310-33.

30. Bauer A, Kirby W, Sherris J, Turck M. Antibiotic susceptibility testing by standardised single disc method. Am J Clin Pathol 1966;45:493-6

31. Meyer BN, Ferrigni NR, Putnam JE, Jacobsen LB, Nichols DE, McLaughlin JL. Brine shrimp: A convenient general bioassay for active plant constituents. Planta Medica 1982;45:31-4.

32. Finney DJ. Probit Analysis. $3^{\text {rd }}$ ed. Cambridge: Cambridge University Press; 1971.

33. Gaudreau C, Girouard Y, Ringuette L, Tsimiklis C. Comparison of disk diffusion and agar dilution methods for erythromycin and ciprofloxacin susceptibility testing of Campylobacter jejuni subsp. jejuni. Antimicrob Agents Chemother 2007;51:1524-6.

34. Paz EA, Cerdeiras MP, Fernandez J, Ferreira F, Moyna P, Soubes M, et al. Screening of Uruguayan medicinal plants for antimicrobial activity. J Ethnopharmacol 1995;45:67-70.

35. Kudi AC, Umoh JU, Eduvie LO, Gefu J. Screening of some Nigerian medicinal plants for antibacterial activity. J Ethnopharmacol 1999;67:225-8.

36. Vlietinck AJ, van Hoof L, Totte J, Lasure A, Vanden Berghe
D, Rwangabo PC, et al. Screening of a hundred Rwandese medicinal plants for antimicrobial and antiviral properties. J Ethnopharmacol 1995;46:31-47.

37. Palombo EA, Semple SJ. Antibacterial activity of traditional Australian medicinal plants. J Ethnopharmacol 2001;77:151-7.

38. Foley W, Lassak E. The potential of bioactive constituents of Eucalyptus foliage as non-wood products from plantations. Publication no. 04/154, Rural Industries and Development Corporation, Australia. 2004.

39. Porter NG, Wilkins A. Chemical, physical and antimicrobial properties of essential oils of Leptospermum scoparium and Kunzea ericoides. Phytochemistry 1999;50:407-15.

40. Russell MF, Southwell IA. Monoterpenoid accumulation in 1,8-cineole, terpinolene and terpinene-4-ol chemotypes of Melaleuca alternifolia seedlings. Phytochemistry 2003;62:683-9.

41. Simić N, Palić R, Randjelović V. Composition and antibacterial activity of Achillea clypeolata essential oil. Flavour and Fragrance Journal 2005;20:127-30.

42. Mondello F, De Bernardis F, Girolamo A, Cassone A, Salvatore G. In vivo activity of terpinen-4-ol, the main bioactive component of Melaleuca alternifolia Cheel (tea tree) oil against azolesusceptible and -resistant human pathogenic Candida species. BMC Infect Dis 2006;6:158.

43. Shafi PM, Rosamma MK, Jamil K, Reddy PS. Antibacterial activity of Syzygium cumini and Syzygium tra ancoricum leaf essential oils. Fitoterapia 2002;73:414-6.

44. Jirovetz L, Fleischhacker W, Buchbauer G, Ngassoum MB. Analysis of the essential oils of Callistemon rigidus (Myrtaceae) from Cameroun by GC/FID and GC/MS. Sci Pharm 1997;65: 315-9.

Cite this article as: Cock IE, Kukkonen L. An examination of the medicinal potential of Scaevola spinescens: Toxicity, antibacterial, and antiviral activities. Phcog Res 2011;3:85-94.

Source of Support: School of Biomolecular and Physical Sciences, Griffith University, Conflict of Interest: None declared.

Announcement

Android App

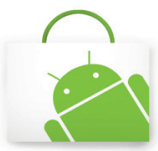

A free application to browse and search the journal's content is now available for Android based mobiles and devices. The application provides "Table of Contents" of the latest issues, which are stored on the device for future offline browsing. Internet connection is required to access the back issues and search facility. The application is compatible with all the versions of Android. The application can be downloaded from https://market.android.com/details?id=comm.app.medknow. For suggestions and comments do write back to us. 